\title{
Rediscovery of Tetragonula praeterita after 1860: an unremarked common stingless bee endemic to Sri Lanka
}

\author{
T.H. Saumya E. Silva, G.C. Prasanga Diyes, W.A. Inoka P. Karunaratne* and Jayanthi P. Edirisinghe \\ Department of Zoology, Faculty of Science, University of Peradeniya, Peradeniya.
}

Revised: 24 November 2017; Accepted: 21 December 2017

\begin{abstract}
Three species of stingless bees are documented from Sri Lanka, namely, Tetragonula iridipennis (Smith), Lisotrigona cacciae (Nurse) and the endemic Tetragonula praeterita (Walker). Tetragonula irdipennis is the well-known, widely distributed stingless bee in Sri Lanka while L cacciae is a recent record of a tear drinking stingless bee from a single site in Sri Lanka. Until the recent rediscovery, T. praeterita was known only from its type specimen deposited in the British Natural History Museum, London with Sri Lanka as its locality and 1860 as its date of description. Location of several stingless bee nests, with an entrance different to that of the well-known $T$. iridipennis, led to the re-discovery of $T$. praeterita. Its nesting sites, characteristics of the nest entrance tube and the morphological and morphometric differences of the worker caste compared to those of T. iridipennis are presented in the paper. Eight species of stingless bees have been reported from the Indian subcontinent. It is possible that more than three species of stingless bees occur in Sri Lanka.
\end{abstract}

Keywords: Lisotrigona, Sri Lanka, stingless bees, Tetragonula.

\section{INTRODUCTION}

Stingless bees (Hymenoptera: Apidae) of the tribe Meliponini are known to have existed in the tropics for well over 65 million years, much longer than the stinging Apis bees (Camargo \& Pedro, 1992; Michener, 2000). The Meliponini are confined to the tropical and southern subtropical areas of the world. They are considered as major pollinators in the tropics (Michener, 1974) and are particularly common in tropical America and Southeast Asia. According to Rasmussen (2013) there are eight species of stingless bees in the Indian subcontinent. The very first stingless bee to be recorded from Sri Lanka was Tetragonula iridipennis (Smith, 1854). The type specimen of this species (deposited in the British Museum of Natural History, London) is from Sri Lanka, Central Province, Kandy (ca. $7.27^{\circ} \mathrm{N}, 80.60^{\circ} \mathrm{E}$, ca. 467 m a.s.1.), according to Rasmussen (2013). Until the recent discovery of a new tear drinking stingless bee from Sri Lanka by Karunaratne et al. (2017), stingless bees of Sri Lanka was known only by the single species, Trigona iridipennis, known as Tetragonula iridipennis since 1961. Moure (1961) addressed the change in the generic name from Trigona to Tetragonula in his classification of the Old World meliponine bees. It has a wide distribution in the island and is known to nest in a variety of wooden structures. In 2017, Karunaratne et al. reported a new stingless bee species Lisotrigona cacciae (Nurse, 1907), from the Knuckles Forest Reserve of Sri Lanka. This was the first record of a tear drinking bee to be reported from Sri Lanka. Rasmussen (2013) in his publication on the eight species of stingless bees of the Indian subcontinent, records yet another stingless bee species, Tetragonula praeterita (Walker, 1860) from Sri Lanka, known only from a single specimen deposited in the British Natural History Museum, and described by Francis Walker in 1860. The stingless bees build elaborate hives often characteristic to a species or to a higher taxon (Michener, 1974; Sakagami, 1982). The individual species are recognised from their nest entrances and often their nest site (Roubik, 2006). A recent survey conducted to record the distribution of nests of stingless bees within the Kandy District revealed the presence of nests with an external nest entrance tube different

\footnotetext{
* Corresponding author (inokap@pdn.ac.lk; (iD https://orcid.org/0000-0002-1483-9494)
} 
from that of typical T. iridipennis. This observation led to further investigations and descriptions; including the distribution of this new nest type in the Kandy District, the morphology and morphometric data analysis for its identification and separation from the well-known T. iridipennis.

\section{METHODOLOGY}

Field surveys were conducted in several locations within the Kandy District ( $7^{\circ} 18^{\prime} 15.84^{\prime \prime}$ N 8042’26.28” E) in 2016 to record the nests of stingless bees, making detailed observations of the type of external nest tube/ entrances. The nest entrances were photographed and the material used to construct the nest tube was identified. From several stingless bee nests having a specific type of entrance tube/types, 55 individuals from each nest type were collected and pin mounted for further identification. The key of Rasmussen (2013) was used for the identification. Photographs showing the characteristic features of nests, specially the nest entrance tube, were taken using a camera. Selected morphometric measurements of the head, based on information given in Sakagami et al. (1996), such as the inner ocellar distance, upper inter ocellar distance, head width, inter-antennal distance and eye length were made using a micro view USB digital microscope $(\times 650)$. The morphometric data were subjected to statistical analysis, sample t-test and principal component analysis (PCA) to determine the extent of variation among individuals from different nests.

\section{RESULTS AND DISCUSSION}

Out of 65 stingless bee nests located, 31 stingless bee nests having a specific type of nest entrance tube were recorded from the study area. All the individuals collected from nests having this specific nest entrance tube were identified as Tetragonula praeterita, thus reporting its rediscovery after 1860 . The nest entrances of T. iridipennis have no entrance tubes and the entrance holes are larger compared to T. praeterita.

Table 1: Morphometric analysis of the variation in head measurements of T. iridipennis (Ti) and T. praeterita (Tp) $(\mathrm{n}=55$ for each species)

\begin{tabular}{|c|c|c|c|c|c|c|c|c|c|c|}
\hline & \multicolumn{2}{|c|}{$\begin{array}{l}\text { Inter - occellar } \\
\text { distance }(\mathrm{mm})\end{array}$} & \multicolumn{2}{|c|}{$\begin{array}{c}\text { Upper } \\
\text { inter - occellar } \\
\text { distance }(\mathrm{mm})\end{array}$} & \multicolumn{2}{|c|}{$\begin{array}{l}\text { Head width } \\
\qquad(\mathrm{mm})\end{array}$} & \multicolumn{2}{|c|}{$\begin{array}{l}\text { Inter - antennae } \\
\text { distance }(\mathrm{mm})\end{array}$} & \multicolumn{2}{|c|}{$\begin{array}{l}\text { Eye length } \\
(\mathrm{mm})\end{array}$} \\
\hline & $\mathrm{Ti}$ & $\mathrm{Tp}$ & $\mathrm{Ti}$ & $\mathrm{Tp}$ & $\mathrm{Ti}$ & $\mathrm{Tp}$ & $\mathrm{Ti}$ & $\mathrm{Tp}$ & $\mathrm{Ti}$ & $\mathrm{Tp}$ \\
\hline Mean \pm SD & $0.47 \pm 0.02$ & $0.41 \pm 0.02$ & $1.31 \pm 0.02$ & $1.19 \pm 0.04$ & $1.91 \pm 0.04$ & $1.79 \pm 0.04$ & $0.21 \pm 0.02$ & $0.19 \pm 0.02$ & $1.27 \pm 0.04$ & $1.21 \pm 0.03$ \\
\hline $\begin{array}{l}\mathrm{T} \text { test } \\
\text { results }\end{array}$ & \multicolumn{2}{|c|}{$\mathrm{T}=17.77$} & \multicolumn{2}{|c|}{$\mathrm{T}=19.01$} & \multicolumn{2}{|c|}{$\mathrm{T}=15.23$} & \multicolumn{2}{|c|}{$\mathrm{T}=5.23$} & \multicolumn{2}{|c|}{$\mathrm{T}=9.83$} \\
\hline
\end{tabular}

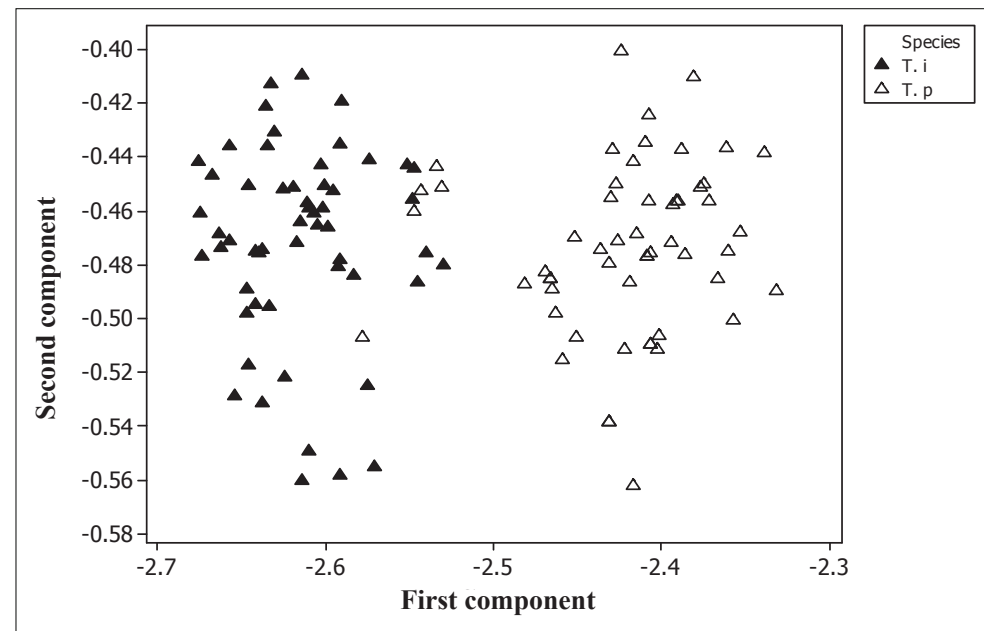

Figure 1: Scree plot of PCA of morphometric data of T. iridipennis (Ti) and T. praeterita $(\mathrm{Tp})(\mathrm{n}=55$ for each species) 

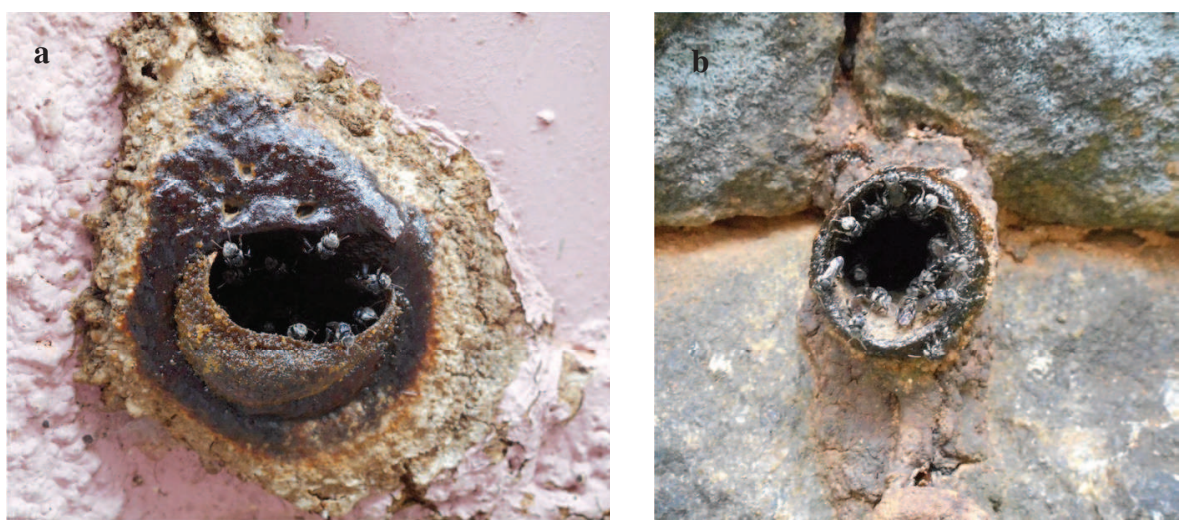

Figure 2: Sticky entrance of T. iridipennis nest. (a) Nest constructed in a crevice of a concrete pillar and (b) a nest constructed in a man-made rock-wall in Peradeniya University premises
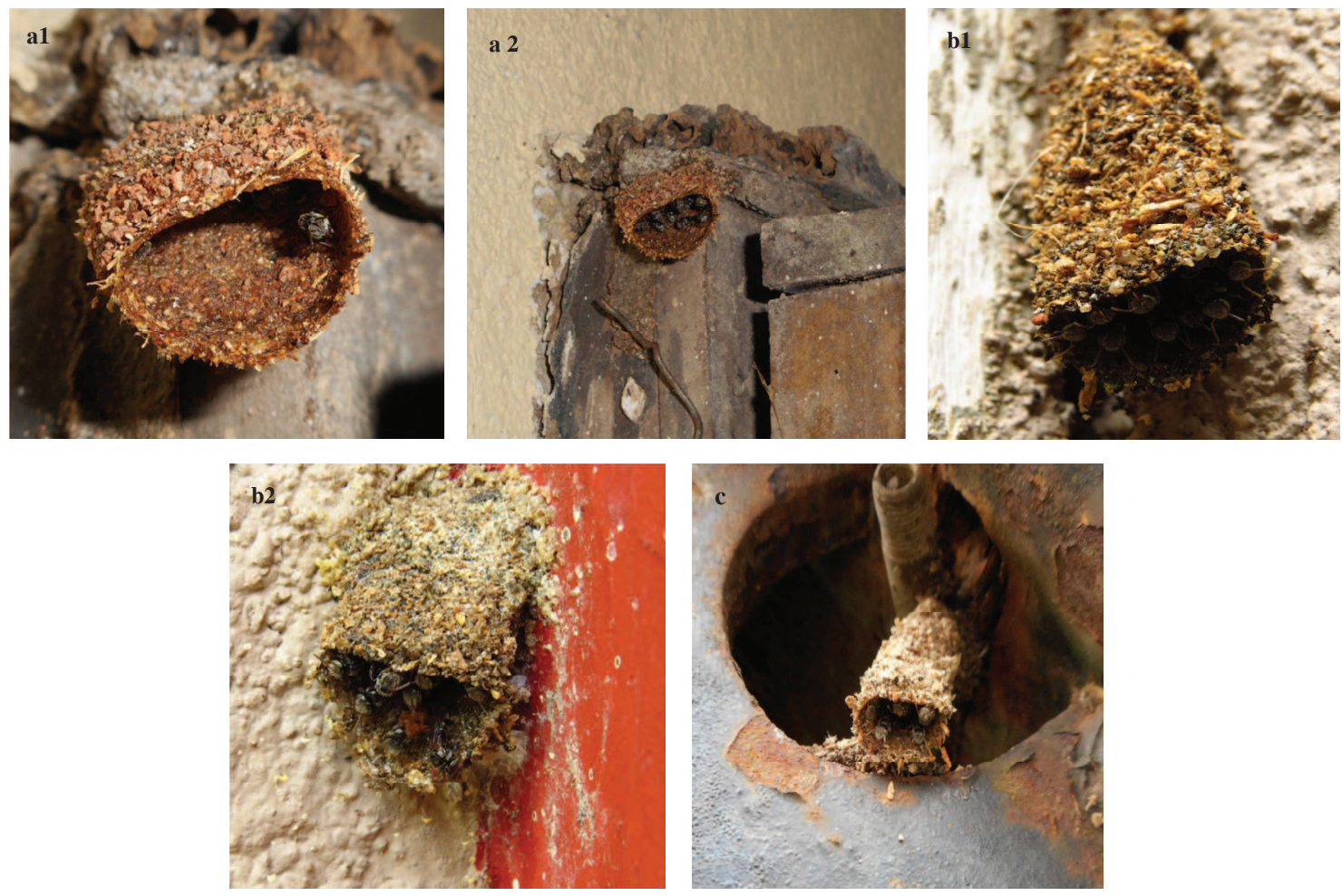

Figure 3: Nests of T. praeterita constructed on different surfaces, showing the nest entrance tube. (a) Nest constructed on the upper left corner of a wooden frame of an electricity meter; (a1) close up of the external nest entrance tube of the same nest showing wood and sand particles glued together to form the rough outside surface; (a2) nest entrance tube being guarded by worker; (b) nest constructed in a crevice between a window frame (on the left) and the cement wall; (b1) close up of nest entrance tube of the same nest, constructed using wood and sand particles in a crevice between a window frame (on the left side) and cement wall (on the right side); (b2) nest entrance tube showing glued sand particles of a nest constructed in a crevice of a wall of an outdoor stair case; (c) nest constructed in an abandoned tire 


\section{Systematic note}

\section{Tetragonula praeterita (Walker, 1860)}

\section{Diagnosis}

Worker female: The two species of Sri Lanka Tetragonula; T. iridipennis and T. praeterita are similar in appearance, the latter species is slightly smaller than the former. The major difference in the worker bee lies in the arrangement of hairs on frons and clypeus of the two species: plumose hairs on clypeus and frons are abundant in T. iridipennis and they are sparse in T. praeterita (Rasmussen, 2013).

\section{Comparison of morphometric data of the head of T. iridipennis and T. praeterita}

Analysis of morphometric data of the variation in head measurements of the worker bees of the two species revealed that there is a significant difference between all measured variables (Table 1). This observation was further confirmed by the PCA, where two distinct clusters are seen (Figure 1). The highest contribution to the variation is from the head-width (covariance $=-0.652$ ).

External nest entrance tube: In nests of T. iridipennis, the nest entrance is sticky (Figures $2 \mathrm{a}$ and $2 \mathrm{~b}$ ) due to resin and is circular-oval with a length of $23 \pm 9.0 \mathrm{~mm}$ (widest part measured) and a width of $17 \pm 6.7 \mathrm{~mm}$ $(n=7)$ (Figure 3). The nests are found mostly in tree trunks and crevices of cement (Figure $2 \mathrm{a}$ ) and rock walls (Figure $2 \mathrm{~b}$ ). In contrast, the nests of $T$. praeterita have a laterally flattened external nest entrance tube with a length of $17.4 \pm 4.0 \mathrm{~mm}$ and a width of $6.0 \pm 0.7 \mathrm{~mm}$ $(n=5)$. Its nests are found in wooden man-made structures such as electricity meter frames (Figures $3 \mathrm{a} 1$ and $3 \mathrm{a} 2$ ), window frames (Figure 3b1), crevices of cement and rock walls (Figure 3b2) and abandoned tires (Figure 3c). The nest tubes were formed of wooden particles, sand particles or both glued together with resin. The nests of the two species are common in houses and buildings within the Peradeniya University premises in the Kandy District.

Behaviour of guarding worker bees at the nest entrance: In T. iridipennis, worker bees that guard the nest entrance did not change their behaviour when an object was moved closer to the nest. In contrast, in $T$. praeterita, the guarding bees at the mouth of the flattened external nest entrance tube moved in fast when an object was moved closer to the nest. Entrance tubes of T. praeterita were kept sealed after sunset, while the nest entrance of T. iridipennis was kept open throughout the day and night. Bees with sticky resin loads in their corbacula were often seen at the nest entrance of T. iridipennis.

Although stingless bees of $T$. praeterita have gone unremarked since its first description in 1860, the present survey shows that its nests are common within the Kandy District sharing habitat with $T$. iridipennis. Extensive field surveys conducted previously by Karunaratne (2004) to explore the bee fauna of Sri Lanka may have missed this species due to incorrect identification of it as $T$. iridipennis, due to the close similarity in their external morphology. Tetragonula praeterita was first synonymised under T. iridipennis by Schwarz (1937), later followed by Moure (1961) and Sakagami (1978). In 2013, Rasmussen identified it as a separate species and included both under the 'iridipennis' species group along with two other species, T. ruficornis and T. bengalensis, all from the Indian subcontinent. Studies on the male genitalia and molecular identification of the four species within this species group will further consolidate their identity at species level. According to Couvillon et al. (2008), the larger nest entrance constructed by T. iridipennis is able to accommodate high traffic at the entrance tube guarded by more aggressive workers, compared to $T$. praeterita. The temporary sealing of the nest entrance tube at night by $T$. praeterita may reduce predator and robber pressure (Roubik, 2006). In contrast, sticky nest entrance of $T$. iridipennis may deter non-flying intruders (Michener, 1974; Roubik, 2006). Nogueira-Neto (1997) showed that stingless bees actively immobilised any intruder to the nest using resin deposited in the nest. Although stingless bees contribute much to the pollination of flowering plants, the nests of stingless bees, particularly of $T$. praeterita are vulnerable to destruction by humans as they also use man-made structures for nesting. The recent survey revealed that more than $90 \%$ of the nests are built on the wooden frames of electricity meters. According to personal information obtained from meter readers, house owners spray the insecticide 'Mortein' to kill the insects not knowing that the nests belong to stingless bees. Therefore, public awareness on the importance of these bees that are harmless is timely for their conservation. The re-discovery of $T$. praeterita many decades after its first identification highlights the importance of conducting regular field surveys to explore the bee fauna of the country. 


\section{CONCLUSION}

The current paper adds one more species, Tetragonula praeterita to the list of stingless bees of the country making a total of three species; T. iridipennis, $T$. praeterita and Lisotrigona cacciae. Thereby, the total bee fauna of the country is elevated to 150 species in 39 genera.

\section{REFERENCES}

1. Camargo J.M.F. \& Pedro S.R.M. (1992). Systematics, phylogeny and biogeography of the Meliponinae (Hymenoptera, Apidae): a mini-review. Apidologie 23(6): $509-522$.

DOI: https://doi.org/10.1051/apido:19920603

2. Couvillon M.J., Wensellers T., Imperatriz-Fonseca V.L., Noqueira-Neto P. \& Ratnieks F.L. (2008). Comparative study in stingless bees (Meliponini) demonstrates that nest entrance size predicts traffic and defensivity. Journal of Evolutionary Biology 21: 194 - 201. DOI: https://doi.org/10.1111/j.1420-9101.2007.01457.x

3. Karunaratne W.A.I.P. (2004). Taxonomy and natural history of bees in selected areas of Sri Lanka. PhD thesis, University of Peradeniya, Sri Lanka.

4. Karunaratne W.A.I.P., Edirisinghe J.P. \& Engel M.S. (2017). First record of a tear-drinking stingless bee, Lisotrigona cacciae (Nurse) (Hymenoptera: Apidae: Meliponini), from the central hills of Sri Lanka. Journal of the National Science Foundation of Sri Lanka 45(1): 111 - 113. DOI: https://doi.org/10.4038/jnsfsr.v45i1.8042

5. Karunaratne W.A.I.P., Edirisinghe J.P. \& Pauly A. (2005). An Updated Checklist of Bees of Sri Lanka with New
Records. MAB Handbook and Occasional Paper Series. National Science Foundation, Colombo 07, Sri Lanka.

6. Michener C.D. (1974). The Social Behavior of the Bees: A Comparative Study, volume 73, No. 87379. Harvard University Press, USA.

7. Michener C.D. (2000). The Bees of the World, volume 1. Johns Hopkins University Press, Maryland, USA.

8. Moure J.S. (1961). A preliminary supra-specific classification of the old world meliponine bees (Hymenoptera, Apoidea). Studia Entomologica 4: 181 - 242.

9. Nogueira-Neto P. (1997). Vida E Criaçao De Abelhas Indigenas Sem Ferrao. Editora Nogueirapis, Sao Paulo, Brazil.

10. Rasmussen C. (2013). Stingless bees (Hymenoptera: Apidae: Meliponini) of the Indian subcontinent: diversity, taxonomy and current status of knowledge. Zootaxa 3647(3): $401-428$.

DOI: https://doi.org/10.11646/zootaxa.3647.3.1

11. Roubik D.W. (2006). Stingless bee nesting biology. Apidologie 37(2): 124.

DOI: https://doi.org/10.1051/apido:2006026

12. Sakagami S.F. (1978). Tetragonula stingless bees of the continental Asia and Sri Lanka (Hymenoptera, Apidae). Journal of the Faculty of Science, Hokkaido University, Series VI, Zoology 21: $165-247$.

13. Sakagami S.F. (1982). Stingless bees. Social Insects 3: $361-423$.

14. Sakagami S., Ebmer A.W. \& Tadauchi O. (1996). The halictine bees of Sri Lanka and the vicinity III. Sudila (Hymenoptera, Halictidae) Part 1. Esakia 36: 143 - 189.

15. Schwarz H.F. (1937). Results of the Oxford University Sarawak (Borneo) expedition: Bornean stingless bees of the genus Trigona. Bulletin of the American Museum of Natural History 73: 281 - 328. 